\title{
The Political and Social Culture of Sandomierz Nobility in the Light of Tomb Inscriptions
}

'Democracy is a government of all the people, by all the people, for all the people'. This classic definition, formulated by Theodore Parker in 1850, at the Anti-Slavery Convention in Boston, repeated in this or slightly modified form, is a source of problems for historians specialising in earlier periods, when the concept of democracy was different. Today, the two initial elements are emphasised. Parker's phrase 'all the people' - although theoretically closer to direct democracy - accentuates the way of exercising the authority, focusing on its form (being, in the practice, almost exclusively parliamentary) and not intentions or results of actions. When confronted, however, with the apparently internally contradictory term of nobles' democracy, that means a democracy limited to a single ruling class, we cannot leave aside the political culture of members of this class; it is the political culture that determines, whether the democracy will be commonly perceived as a government of 'all' the noble 'people', by 'all' this 'people' and for 'all the people', not only the nobles. It is important also because, in spite of class limitations, the percentage of population granted with active suffrage was several times higher in the Polish-Lithuanian Commonwealth than in countries where the democracy was restricted by property - and not class - privileges, as it was in England or, to some degree, in Sweden. Moreover, considering the material status of voters, the active suffrage was granted in the Commonwealth to members of different social classes.

The notion of political culture has been introduced to Polish historical thinking in 1932 by Józef Siemieński, but an interest in this issue can be 
found already in works of Józef Szujski and Michał Bobrzyński, while Konfederacja $i$ rokosz by Adrian Rembowski and Rzady sejmikowe by Adolf Pawiński initiated a series of publications on the nobles' political culture in the Commonwealth and Europe. A monograph written by Edward Opaliński ${ }^{1}$ entitles us not to discuss extensively works of our predecessors, but to focus on previously untouched fields of research. The most important of these seems to be the detachment of the Old Polish political culture from the issues of social culture sensu largo; thus the majority of scholars - with an exception of Władysław Łoziński and Andrzej Zajączkowski - was interested almost exclusively in issues of government and state, king, sejm and sejmiks, presented from the point of view of nobles and magnates - the political elite that participated in them.

This is, actually, characteristic also of other dissertations on Old Polish culture. A comment made by Wacław Urban, that one of the most prominent scholars specialising in the Old Polish culture describes in his books 'the way of thinking of the elites and Protestants, while omitting poor noblemen', ${ }^{2}$ was doubtless true, but the same concerns the vast majority of works on Old Polish political culture. This resulted not only from certain methodological premises, but also - and perhaps mainly - from the lack of non-availability of adequate source material to draw any conclusions concerning more populous social classes - that 'minor' noble people. And without knowing this people, it is impossible to understand the nobles' democracy. In recent years, however, a source has been finally published, of an exceptional significance for the study of mass culture - Corpus Inscriptionum Poloniae. It is far from being complete, especially as frequent changes in the administrative division - which happens in every generation, if not more often - overturns financial base and very principles of such projects, depending on the good will of local administration. However, the comical, although inevitable, classification of the inscriptions according to changeable geographical criteria creates an opportunity to conduct interesting comparisons and to analyse the processes of developing local cultural patterns that not always coincide with administrative divisions. The series was initiated with fascicles describing the former Kielce voivodeship and neighbouring

1 E. Opaliński, Kultura polityczna szlachty polskiej w latach 1587-1651, Warsaw, 1995.

2 W. Urban, [review of J. Tazbir, Świat panów Pasków, Łódź, 1986], Odrodzenie i Reformacja $w$ Polsce, 32, 1987, p. 329. 
areas which eventually made up the left-bank part of the Old Polish Sandomierz voivodeship together with fragments of Cracow and Sieradz voivodeships as well as parts of Mazovia and Kujawy - regions particularly abounding epigraphic material. The Sandomierz district may be considered, for many reasons, as being representative of the Old Polish nobles' culture. Thus we decided, for the sake of the present research, to use data from Sandomierz district, only occasionally referring to those from other areas. The latter are well known, but they coincide with what can be concluded concerning Sandomierz, and thus do not contribute much to the study. We have already presented certain conclusions based on material available over a dozen years ago, as well as on field research in the historical Cracow voivodeship. Those concerned, however, quite different problems - mainly those of emotional culture - only occasionally raising the issue of political culture patterns. ${ }^{3}$

The material used here consists largely of numerous epitaphs, which are conventional and full of banalities, but nevertheless they tell a lot about personal models of that time. Conventions that influenced the inscriptions are not only of local origin. The Middle Ages had no great influence on their shaping, but the Renaissance revived the memory of ancient conventions and their literary form. Latin inscriptions, that have been meticulously copied by numerous collectors, researchers and travellers since the sixteenth century became the source of ideological, formal and stylistic models. ${ }^{4}$ Thus many Old Polish inscriptions retained 'the layout and even the contents inspired by Roman epitaphs'. ${ }^{5}$ This phenomenon was, actually, much more common in Poland than in many other European countries. The influence of the German-speaking culture on the ideological contents was insignificant, in spite of German etymology of the term 'grobsztyn', which was commonly used at that time. Renaissance Italian epitaphs were, of course, well known to our ancestors, but only rarely imitated, because they list usually the offices held by the deceased, less often describing his deeds or personality. Of greatest interest are perhaps those that display a bourgeois pride, so similar to the patrician pride of the citizens of Cracow, Gdańsk or Lviv. French epitaphs are often an abridged version of a notarial deed: 'Here

3 S. Grzybowski, 'Skamieniate żale. Staropolskie inskrypcje nagrobne', Odrodzenie i Reformacja $w$ Polsce, 35, 1990, pp. 77-90.

4 Rzymskie epitafia, zaklęcia i wróżby, ed. by L. Moroni Mazzolani, Warsaw, 1990, pp. 146, 147.

5 S. Kasprzysiak, 'Nie może być inaczej' [introduction], ibid., pp. 22-23. 
lies $\mathrm{X}$, who bequeathed to this church so and so much, in his will dated so and so'. The famous English epitaphs seem to be the most beautiful ones, but they are of a later date. The epitaphs dating from the sixteenth century are found extremely rarely among them, and their contents was controlled by the College of Arms, which lost much of its importance in the seventeenth century, but nevertheless it was because of this control that the contents of epitaphs remained restricted to scarce information, given in a succinct and lucid form. A church so old as Bath Abbey comprises 640 funerary monuments; however the oldest one dates from 1572, and only 26 date from the seventeenth century (there were 32 of them in $1770^{6}$ ). These numbers are hardly comparable with Poland where - despite of historical turmoil - older epitaphs still predominate. It was only in the eighteenth and nineteenth centuries that the profusion of well preserved, witty and original epitaphs are found. Many of them are charming and display a British speciality: jokes, smile through tears and philosophical reverie. ${ }^{7}$ In this respect, English epitaphs are close to numerous Roman inscriptions, but also to those Old Polish ones that emphasise the emotional aspect of grief and mourning, although usually it is not personal models that are important there, but rather individual features of the deceased and the uniqueness of human fate. On the other hand, Old Polish epitaphs emphasise the conformity to accepted personal models. The fact, that the models are of political and social nature and formed through changing and turbulent history of the country, adds to these inscriptions a huge importance that cannot be compared to foreign, more individualised epitaphs.

It is obvious that an epitaph glorifies merits of the deceased, but omits any deviations from accepted rules. In this respect, epitaphs present a picture that is completely different from the vast majority of literary sources, for example, the satirical writings of the greatest of Sandomierz citizens, Jan Kochanowski. Thus the results of research based on this category of sources do not invalidate numerous negative - although sometimes exaggerated - opinions about the political culture of the nobles' society. The former are, however, an excellent supplement to the latter. Inscribed on tombstones, succinct, synthetical biographies of

6 B. Stace, Bath Abbey. Monuments, Bath, 1993, p. 8.

7 G.N. Wright, Discovering Epitaphs, 2nd ed., Princes Risborough, 1996 (Discovering, 144), p. 19 and passim. Cf. K.A. Esdaile, 'The Renaissance Monuments in Buckinghamshire', Records of Buckinghamshire, 25, 1947, pp. 32-45. 
the nobles - and not only theirs - describe models, but also attitudes towards political events and civic duties, presenting their hierarchy, and also their influence on the social position of the deceased. Last but not least, the chronological sequence of the events mentioned in an epitaph mirrors the process of a noble being prepared for his civic service, as envisaged by the inscription's author. Quite often, it can be observed that apparently established conventions were being modified in an interesting way as a result of specific political events and slow cultural changes; new conventions were formed, and then expanded, and interiorised. Thus the political culture of the nobility appears as a result of a defined, dynamic process and its determinants rather than as a static picture of formed and petrified civic attitudes.

Among these conventions, an important one was the emphasising of the established place of an individual within the social hierarchy. Rather than to the declarative equality of the nobles, it conformed to proverbial sayings like 'pilnuj szewcze kopyta' (mind your last, shoemaker). The theme of being satisfied with one's fate is quite often encountered in tomb inscriptions of people enjoying certain social prestige, not necessarily by birth, but rather because of an official or priestly function, for example, a parish priest Jan Stefański 'nobilis parvo tamen contentus', ${ }^{8}$ or Tomasz Kawałkowski of Busko, first a clerk, then podstarości and district judge of Nowy Korczyn, 'animum habens sua sorte contentum'. ${ }^{9}$ It should be remembered that similar examples of noble officials are found also in Cracow - a governmental clerk and royal secretary Rysiewicz, ob. 1779, was 'wart był większych względów, lecz w Fortuny mierności bezpieczniej dochował ostrej cnoty, Bóg świadek, że w niej nieszwankował' (was worth of greater favours, but in Fortune's remained true to the highest virtue; God witnessed that he didn't lack it). ${ }^{10}$ In Miechów district, close to the borders of Sandomierz region, an impoverished nobleman was content with his fate - Marcin Mazowiecki, 'ze wsi którą Mazowszem na Dobrzyniu zową, gdzie się zawsze rodziła szlachta z dobra sławą’ (coming from a village called Mazowsze in Dobrzyń, where always noblemen of a good name were born). ${ }^{11}$ It is another proof of how accurately Mickiewicz described the atmosphere of the countryside.

8 Corpus Inscriptionum Poloniae, [various places], 1975-, 1/2, p. 114, 1635 (hereafter, only vol./no., p., and ob., are given).

$91 / 3$, p. 48, 1637.

10 Cracow, Trinity Church, Madonna of the Rosary Chapel.

11 J. Wiśniewski, Dekanat miechowski, Radom, 1917, p. 141. 
On a higher level of the social hierarchy, there was a noticeable interest with family tradition among the nobles in the seventeenth century; Aleksander Ossowski, komornik grodzki (municipal bailiff) of Opoczno, member of the interregnum vigilance committee of Sandomierz (sędzia kapturowy sandomierski) and judge of the Crown Tribunal, explained his status quoting not only his legal erudition and experience, but also the fact that he was 'vetustate griffinorum familiae phaenicem', apparently in case someone was unaware of this. ${ }^{12}$ The epitaph of Matgorzata Baranowska, wife of a Sieradz voivode, contains a detailed list of her ancestors, including her grandmother; evidently, her marrying into a senatorial family had to be genealogically substantiated. ${ }^{13}$ In the epitaph of Gertruda ('Gierusza') Kościelecka, wife of a Sieradz voivode, her daughter did not fail to mention herself to be the wife of one of the highest-ranked ministers, Great Crown Marshal Andrzej Opaliński. ${ }^{14}$ Andrzej Rej, son of Mikołaj, bore - according to his wife Katarzyna of Dembiński, chancellor's daughter - 'nomen quae patriae et grata fuerat Deo'; it is not without a reason that a religious argument supplements the genealogical one, considering the heterodox background of the deceased. ${ }^{15}$ And when it happened that a homo novus achieved a senatorial rank, such fact had to be precisely substantiated - even in the case of such famous and distinguished figure as Stefan Bidziński, the Sandomierz voivode, hero of Chocim and Vienna. ${ }^{16}$

The justification had not necessarily to be of a military nature. Jan Wojciech Rakowski, who died prematurely in 1639, son of Wizna castellan, he himself a voivode of Witebsk and highly regarded diplomat, distinguished himself not only with 'splendore domus', but also with 'factorum gloria', especially his missions to England, ${ }^{17}$ as noted by his brother, who erected his tombstone. Thus wordy epitaphs of nouveau riches (of a later date) - for example, that of Franciszek Hieronim Granowski (ob. 1735), who was a royal musketeer in Paris when young, or Adam 'comes' Małachowski (1767) - should not be seen merely as an indication of vainglory or complexes, but they were also intended as

$121 / 3$, p. 138, 1669.

$131 / 3$, p. 112, 1631.

14 Sprawozdania Komisji do Badania Historii Sztuki w Polsce, 4, 1889-1891, p. LVI.

15 1/2, p. 149, 1601.

16 1/3, pp. 163-64, 1704.

17 W.F. Rakowski, Pamiętnik Wielkiej Wojny Pótnocnej, ed. by M. Nagielski and M. Wagner, Warsaw, 2002, pp. XLVI-XLVII. 
a justification of their joining the ranks of aristocracy or assuming a title. ${ }^{18}$ It is also noteworthy that on the above-mentioned eighteenth-century tombstones it is no more the alleged family's antiquity, but rather personal merits. Moreover, it happened in an age when the reverend Chmielowski and others complained about nouveau riches inventing fantastic genealogies for themselves; it was not, however, a standard of the time that they reviled, but rather a deviation from it. ${ }^{19}$ It should be also remembered that tombs of the members of grand families are only rarely found in provincial churches; usually they have been erected in famous cathedral churches. Even if such a person wanted to be commemorated in his homeland - as did Krzysztof Szydłowiecki in 1532 - the only purpose of this was to show 'jakie akcesoria jego władzy i potęgi mają być przekazane przyszłości' (which attributes of his power are to be transmitted to posterity) - as aptly noticed by Helena and Stefan Kozakiewicz. ${ }^{20}$ In Sandomierz district, such offices as pantler (stolnik), starosta, bailiff (komornik), county castellan (kasztelan drażkowy) etc. occur most commonly on epitaphs, apart from nobles without any titles.

Everyone in that circle was expected to mind his position and function in the class and family hierarchies. The hierarchy of social values was grounded in the family life, according to which the emotional patterns were often considered also as models of the social culture. Naturally, it had to be a harmonious, 'sine querela' life, like, for example, that of $\mathrm{Mr}$ and Mrs Gawroński from somewhere around Kielce. ${ }^{21}$ All credit for this was usually given to the wife, as it was in the case of Elżbieta Ważyńska from around Małogoszcz, who 'viginti cohabitavit annis sine querela. . ${ }^{22}$ Another example of a model wife was Zofia Śliwińska, described as 'zwierciadło cnót i posłuszeństwa' (a mirror of virtues and obedience). ${ }^{23}$ The most often praised virtue of an Old Polish matron is, however, generosity towards the poor - and to the church. Zofia Cechowska, the wife of a Kielce starosta, 'was the mother of the poor', ${ }^{24}$ Marianna Wilczewska was praised

18 6, pp. 277-79, 1735; 6, pp. 167-69, 1767.

19 Cf. S. Grzybowski, ' $Z$ dziejów popularyzacji nauki w czasach saskich', Studia i Materiaty z Dziejów Nauki Polskiej, Series A, 7, 1965, p. 118.

20 H. and S. Kozakiewicz, Renesans w Polsce, Warsaw, 1987 (Dzieje sztuki w Polsce, 3), p. 74.

$211 / 1$, p. 58, 1582.

$221 / 2$, p. 111, 1630.

$231 / 1$, p. $97,1643$.

24 1/1, p. 92, 1630. 
for 'jałmużny co hojnie ubogim rozdała, osobliwie też konwent wielce ratowała' (charities that she generously gave to the poor, and she used to save the convent). ${ }^{25}$ The theme is quite well known in other regions, from tombstones of noble and bourgeois women in country churches, but also from churches of Cracow and Warsaw. ${ }^{26}$ It has been written about a wealthy Jewish woman buried in Przytyk that 'ręce jej otwarte były dla miłosierdzia' (her hands were always open to give charity), and that 'czyniła dobrze i sprawiedliwie wszystkim wstępującym w jej progi, zarówno bogatym, jak biednym' (she behaved well and justly towards everyone, a wealthy and a poor, who set foot in her house), ${ }^{27}$ this being another example of how similar were the ideals of different faiths in the Commonwealth, ${ }^{28}$ although among Catholics, the model of a merciful parson was also greatly valued. Actually, it was not the poorest priests in godforsaken parishes who supported the poor, but rather those who achieved a higher level in social hierarchy, one of them being a noble, ${ }^{29}$ other a canon, ${ }^{30}$ another took pride in an intimate acquaintance with bishop Zadzik, ${ }^{31}$ yet another combined the epithet of 'pater pauperum' with the title of philosophy doctor. ${ }^{32}$ Invoking the charity towards the poor was less often encountered among noble laypersons, and it apparently disappeared in the seventeenth century. In Końskie, Hieronim Konecki (ob. 1564) 'pauperibus semper fuerat benignus', according to his son Jan, chief steward (ochmistrz dworu) and treasurer (podskarbi) of Anne Jagiellon. ${ }^{33}$ A nobleman buried in Lisów in 1589 was kind to his subjects and generous to the poor, according to the inscription written by his son after $1621 .{ }^{34}$

$251 / 1$, p. $70,1683$.

26 For example, Teresa Balcerowiczowa, ob. 1690, Cracow, Dominican Monastery, Cloister; Dorota Sroczyńska, 'kupczyna krakowska' [wife of a merchant from Cracow], ob. 1689, Warsaw, New Town, Dominican Church.

27 7/1, pp. 116-17, 1770.

28 Cf. S. Grzybowski, 'Epitafia żydowskie w Polsce doby sarmatyzmu. Studium porównawcze', in Żydzi w Matopolsce. Studia z dziejów osadnictwa i życia spotecznego, ed. by F. Kiryk, Przemyśl, 1991, pp. 49-58.

$291 / 4$, p. 46, 1553.

$301 / 4$, p. $68,1641$.

$311 / 3$, p. $112,1678$.

$321 / 3$, p. 161,1713 or 1717.

$331 / 5$, p. $83,1564$.

$341 / 3$, p. 78, 1589. 
Charity to the poor and kindness to the subjects appears thus as a specific civic duty. That tradition was, actually, a long-lived one. I remember myself that Mrs Nina Morstinowa visited newly delivered mothers in Pławowice to help them with the first bath and to give them a layette, lugging of which was sometimes my duty. Many years later, in the still manorial England, I observed the wives of my English colleagues taking very seriously their social responsibility towards local people. Usually, such responsibilities rest only on those of a high enough social position, not overburdened with other duties.

The other duties, in the case of noble women, included the care for children, especially the youngest ones. According to the well known research carried out by Philip Ariès, the 'discovery of a child' - that is, the beginnings of the parental love and care are to be dated to the turn of the sixteenth and seventeenth centuries. It was at that time that first tombstones for children have been erected in France (1584) and in England (1607), as independent monuments rather than as an element of a family tomb; in England, actually, the example comes from the top, as the first tombstones belong to royal children. ${ }^{35}$ In Poland, the phenomenon can be observed much earlier: the tombstone of Rafał Ocieski in the Dominican Monastery in Cracow dates from 1547. Only slightly later (ca. 1555) is the tombstone of Kasia Pilecka in Pilica, carved by Padovano. It was in the Sandomierz region, even before the first children epitaphs, that the most famous local poet, Jan Kochanowski, gave voice to his parental love and emotional maturity that arose, ahead of the Western Europe, in the Commonwealth. ${ }^{36}$ The impact of Kochanowski's work, clearly visible in his homeland, encompassed also other areas, as evidenced by heartbreaking epitaphs, for example, that dedicated to two years old Kasia Duninówna in Opoczno ${ }^{37}$ or less than three years old Barbara Stradomska in Kalwaria. ${ }^{38}$ These are paralleled by more modest, but nevertheless touching remembrances, as, for example, that of a Polonised Scotsman who bewailed his four years old son ${ }^{39}$ or an epitaph to a boy murdered, together with his mother, by Swedes during the Deluge. ${ }^{40}$

35 Ph. Ariès, L'enfant et la vie familiale sous l'Ancien Régime, Paris, 1973, Points H20, pp. 64-65.

36 Grzybowski, 'Skamieniate żale..., op. cit., pp. 77-88.

37 6, p. 157, 1616.

38 Ob. 1673. Kalwaria Zebrzydowska, corridor from the monastery to the barnyard, epitaph not mentioned by the Catalogue of Art Monuments in Poland.

$397 / 1$, p. $83,1663$.

40 1/2, p. 160, 1657. 
In the upbringing of the noble youth, a gradation of goals is visible. Admittedly, it was not as clearly defined as it was in the epitaph of a young Lipski in Stary Sącz - who, because of his premature death, could not 'inszych laty gonić, sławą dźwigać dom Lipskich, Polski mieczem bronić' (to equal others in years, to grace the house of Lipski with his own fame, to defend Poland with sword); but nevertheless it indicated the sequence: learning - knightly service - civic activity. In epitaphs the character shaping was quite rarely emphasised, and it is only in inscriptions of other provenance - for example, in altar inscriptions - that a motto of a doubtless biblical origin appears here and there, for example, extolling 'Męża, który nałożył jarzmo na młodość swoją’ (a man who put a yoke on his youth). ${ }^{41}$ An epitaph secular in its character would state at most that a deceased thirteen years old boy 'żył w naukach uczciwych' (lived in accordance with honest lessons). ${ }^{42}$ Then, however, the evaluation criteria of education have changed. In the sixteenth century specific studies - for example, in law ${ }^{43}$, or sometimes a practice in the court service, in the Crown Chancellery, were considered as such. In the seventeenth century it had to be a travel abroad. The mentioned already parish priest Stefański travelled in his youth 'cum principe regni'. Considering the date of his birth (ca. 1562) it was not one of Vasa princes whom he accompanied, but rather one of the nephews of King Stephen. ${ }^{44}$ The canon Mikołaj Próchnicki, a relative and foster child of Lviv archbishop Jan, studied in Germany and in Italy. ${ }^{45}$ Jerzy Rokicki - the proprietor of Szumsk and notorious for the Raków scandal, first soldier and then a priest - although 'educatus paucus', he, however, 'perspired and freezed' in Hungary, Germany, Flanders, Netherlands, France, Italy and Spain. ${ }^{46}$ In the case of Krasuski brothers, 'Muzy młodości $\mathrm{w}$ obcych krajach' (Muses of youth in foreign countries) preceded their being 'obrońcy ojczyzny w polu marsowym' (homeland's defenders in the field of Mars). ${ }^{47}$ Mikołaj Krasuski, Małogoszcz castellan, got acquainted with Muses first in his homeland and in foreign travels, to serve then Mars whom he exchanged finally for Themis. ${ }^{48}$

\begin{tabular}{ll}
\hline 41 & $1 / 2$, p. 126. \\
42 & $1 / 2$, p. $150,1607$. \\
43 & $1 / 3$, p. $103,1584$. \\
44 & $1 / 2$, p. $114,1635$. \\
45 & $1 / 1$, p. $88,1620$. \\
46 & $1 / 3$, p. $183,1640$. \\
47 & $1 / 4$, p. $69,1670$. \\
48 & $1 / 3$, p. 96,1706
\end{tabular}


In the seventeenth century, foreign travels are among the most valued elements of education of a wealthy nobleman or a rich clergyman of a noble descent. In epitaphs of ordinary parsons almost exclusively studies at the Cracow Academy are mentioned. And it is not only theological studies. On the contrary, even a doctor of both laws was found quite often among priests, regardless of their social status. The title could have been held by a bourgeois priest of foreign origin as well as by an archbishop's nephew, Hieronim Solikowski. ${ }^{49}$ Besides, there were doctors of philosophy ${ }^{50}$ and theology, ${ }^{51}$ as well as a doctor and professor of Collegium Minor and Collegium Vladislaviensis (Nowodworski's). ${ }^{52}$ At a later date (1757), there was also a superior of mansionaries (starszy mansjonarzy), who was not only 'litteris instructus' at the Cracow University, but also 'he went through' economy. ${ }^{53}$ It is a clear sign of a new, Enlightenment utilitarianism. Characteristically, I have not encountered any mention of studies in epitaphs of townsmen and officials (although numerous interesting examples are found there) in spite of the fact that graduates of Zamojski Academy might be expected among them, as many inhabitants of Sandomierz region (especially those coming from lower classes) studied at that school. ${ }^{54}$

Thus: learning first, and then service. In the sixteenth century it was still the royal service, most often as a royal secretary - which was a particularly honourable function for a scion of a not very famous family, like Jan Krzecki (ob. 1599). His wife, who founded the tombstone, emphasised proudly that he served three kings: Sigismund II Augustus, Henry and Stephen. ${ }^{55}$ In the turbulent seventeenth century, however, it was the armed service that came to the fore. Stefan Czarniecki himself is described in his epitaph as 'miles et aulicus' in his youth, while his brother Stanisław 'prius militiae quam aetati generose servivit', though at a later date he served also at the court of Constance and Wtadystaw. ${ }^{56}$

$491 / 5$, p. 110, 1631; 6, p. 111, 1631; 1/5, p. 167, 1612; 6, p. 130, 1667.

50 For example, 1/4, p. 50, 1697.

$511 / 4$, p. $70,1702$.

$521 / 3$, p. $71,1664$.

$537 / 1$, p. 92, 1757.

54 Album studentów Akademii Zamojskiej 1595-1781, ed. by H. Gmiterek, Warsaw, 1994 (Archiwum Dziejów Oświaty, 11), editor's introduction, p. 21, and passim, by the index of places, powiats, and deaneries.

$551 / 4$, p. 178.

$561 / 5$, pp. $64,65$. 
In the second half of the century, the court service - even in the capacity of a secretary - is no more mentioned on tombstones of nobles, and it is only clergymen who boast their being secretaries serving three subsequent kings, as did abbot Mikotaj Leżeński from Wachock (ob. 1680). ${ }^{57}$ Piotr Zatuski (ob. 1647) served the Commonwealth in Moldavia, Wallachia and Hungary, seizing every opportunity, and thus he was appointed the Standard-Bearer of Rawa. ${ }^{58}$ Walenty Chomentowski died in 1603, but it was not before 1647 that his sons erected a tombstone for him; in the epitaph, they praised fathers war exploits under Sigismund II Augustus, Stephen Báthory and Sigismund III, mentioning also their own battles with Turks, Muscovites, Swedes and Wallachians. One of them was a Bernardine monk, but nevertheless he vaunted that owing to this fact he fought 'in Christi perpetuam militiam'. ${ }^{9}$ Franciszek Balcerowicz, podstoli of Bracław, boasted of having been first 'recommended to the world by war games that were the beginning of his great fame' ('zaleciły światu wojenne zabawy, bo te były początkiem wielkiej jego sławy'), an then he gave up Mars fields for lordly chambers ('z pól Marsowych udał się na pańskie pokoje'), where he 'served a hetman and a chancellor' ('hetmańskie i kanclerskie traktował usługi'). ${ }^{60}$ Fathers' deeds were the pride of children: Anna Jakubczykowa has been described as the daughter of Piotr Łaszcz, Báthory's colonel fallen at Newel, the epitaph of seventeen years old Barbara Lanckorońska, hetman's daughter, lists the triumphs of her father, who is described as 'patriae libertatis vindex vigillantissimus'. ${ }^{61}$ Such deeds were recommended for children, even ordered. 'Gdy do męskiego wieku będziesz przychodził, rycerskie ćwiczenie jest szlachcicowi najprzystojniejsze; tem się paraj, próżnowania jako powietrza się strzeż (When you will approach the manhood, knightly exercise befits a nobleman; in that you should engage, while idleness do avoid like the plague) - admonished hetman Stanisław Żółkiewski his son in his testament. ${ }^{62}$ It was not accidentally that, since the time of King Stephen, the 'service', regarded as an obligatory element of young nobles' upbringing, was more and more often a military one rather than at the court. Even the very notion of that service evolved

$571 / 5$, p. 171.

58 6, p. 160.

$597 / 1$, pp. 130-31.

60 Cracow, Dominican Monastery, Cloister.

$611 / 4$, p. $150 ; 1 / 3$, p. 157.

62 A. Bielowski, Pisma Stanistawa Żótkiewskiego, kanclerza koronnego i hetmana, Lviv, 1861, p. 174. 
in a significant way. In the first half of the seventeenth century, the war appeared to be an ominous, but distant - at least here, in the midland phenomenon, encountered only in reports from Livonia or Ukraine, ${ }^{63}$ in the mid-seventeenth century becomes something very near, and then - ubiquitous. From graffiti scribbled on walls, warning about 'Chmiel' or 'Krzywonos' ${ }^{64}$ through numerous mentions of persons murdered by Swedes, Cossacks, Rákóczi's Hungarians; a vivid memory of this lasted at least till the middle of the next century. ${ }^{65}$ Thus what happened was increasingly often that the military service was no more considered as a stage in the education of a noble youth, but rather - which is clearly visible also in the quoted above examples - as a burden. 'Comes' Adrian Szumski (ob. 1632), when serving in Livonia, Wallachia and Prussia, 'suffered cold, plague, heatwave, and when thirsty, he had to draw water with his basinet' ('cierpiał zimno, powietrze, ciepła upalenie, musiał podczas wodę pić szyszakiem $\mathrm{w}$ pragnienie'). ${ }^{66}$ The duty, that became widespread at that time, did no more glamorize a man so much, and it was less valued than the increasingly difficult civil service that, indeed, was aimed at preserving the domestic peace.

Not surprisingly, the preservation of the domestic peace acquired qualities of intolerance towards those who dared to think differently. It was not only Wespazjan Kochowski who considered Protestants as 'sukienki rozrywacze, którą tkano w jedności' (tearers of a gown which has been woven in unanimity). ${ }^{67}$ Between the end of sixteenth and the middle of eighteenth century, the abandonment of a 'heresy' by those who have been brought up in it was another reason to pride, ${ }^{68}$ as was fighting 'heresies'; in epitaphs, the fight against heresies was quite easily reconciled with the description of the deceased as 'pacis fraternae charitatis amans' ${ }^{69}$ It would be ahistoric, to examine this phenomenon merely as a persecution and intolerance or to narrow it to the Commonwealth only. In the eighteenth century, it has a whole series of parallels in other,

63 For example, 6, p. 299, 1602; 1/5, p. 72, 1645.

$641 / 3$, p. 125.

$651 / 1$, p. $74,1 / 2$, p. $160 ; 1 / 3$, p. $49,1 / 5$, p. $173 ; 7 / 1$, pp. $89,102 \mathrm{ff}$.

66 Przasnysz, Observant Church, see, Tygodnik Ilustrowany, 3, 1861, p. 208.

67 Cf. S. Grzybowski, Sarmatyzm, Cracow, 1996, p. 57.

68 For example, 1/4, p. 34, 1580; 1/1, pp. 136-37, 1629; 1/5, p. 126, 1682; 1/1, p. 114, 1744, cf. J. Wiśniewski, Historyczny opis kościotów, miast, zabytków i pamiątek w Olkuskiem, [Marjówka Opoczyńska], 1933, p. 40.

$691 / 1$, p. 106; $1 / 3$, pp. $143,147$. 
apparently tolerant countries; in the Exeter cathedral, I have found an evidence of such a specific - paradoxical in fact - attitude, in the epitaph of an Anglican cleric who was 'an opponent of the persecution and of the idolatry' at the same time. The faith was, actually, an essential element of social unity, as such particularly valued in times of danger. When a German protestant newsletter informed in 1656 that Sandomierz, occupied by Swedes, has been regained by Poles 'durch der Jesuiten Pracktiquen', ${ }^{70}$ it was a proof that the opposite side also understood the mechanism. In nobles' epitaphs, it manifested itself as equating the fight for the homeland (for example, against 'infidel' Swedes or Cossacks) with the fight for the faith. ${ }^{71}$ It was because of these dangers, that donors and authors of inscriptions perceived the history mainly as contemporary events. There are only a few inscriptions, usually commemorative ones, that invoke donors of former times: Casimir the Great, Jagiełło, patron saints or eminent monks. ${ }^{72}$ These are found next to commemorative or thanksgiving inscriptions mentioning blazes, plagues, ${ }^{73}$ or foreign invasions. Thus the history - earlier already presented with the preponderance of the interests of the church in mind - was becoming more a religious than a civil one.

Has it changed in the eighteenth century, in the Saxon era? The ideology of the Golden Liberty appears to us as a thorn in the political consciousness of Old Polish nobility. However, when it is mentioned on tombstones - as 'aurea Polonorum libertas' in the epitaph of Aleksander Krasicki, castellan of Wiślica (ob. 1730) - it was apparently because of its relationship to war exploits, judiciary or parliamentary activity. ${ }^{74}$ The Golden Liberty was therefore equal to a service for the country, which is effective through 'scientia' and 'fortuna'. Fortuna and the knowledge acquired in foreign countries' were useful also for Józafat Szaniawski, Crown Chamberlain. ${ }^{75}$ It is not only tombstones of the Załuski family that reflect the drive for knowledge, but also the above-mentioned example of the superior of

70 K. Zawadzki, Gazety ulotne polskie i Polski dotyczace XVI-XVIII wieku. Bibliografia, vol. 1, Wrocław, 1977, p. 152, and vol. 3, Wrocław, 1990, p. 40.

71 For example, 1/3, 1656, p. 49.

72 For example, 1/2, p. 101, 1595; 1/4, p. 76, 1672; 1/3, p. 43, sixteenth/seventeenth century; $1 / 2$, p. 107,$1599 ; 1 / 1$, p. 141 , fresco repainted [?] after $1777 ; 1 / 5$, pp. 175-76, fresco undated.

73 7/1, p. 126, 1622; 7/1, p. 88, 1744; 1/5, pp. 128-29, 1711.

$741 / 3$, p. 98.

75 1/2, p. 158, 1740. 
mansionaries, who 'went through' economy. ${ }^{76}$ An attempt to categorise Old Polish models - which reflects not only their endurance, but also a new spirit of orderliness - can be clearly seen in the lengthy epitaph of chancellor's wife Izabella Małachowska. When listing titles and achievements of his husband - and even those of his father-in-law - she emphasises that both served: 1) Regni, 2) Regi, 3) Legum, 4) Patriae, 5) Nobilitatis, 6) as a Civitatum Regiarum defensor (at sejm) and finally 7) Iustitiae. ${ }^{77}$

As the most appropriate summary of the development of political and civic models, two examples of the Bystrzonowski family may be quoted. Michał, a royal chamberlain (ob. 1789), 'obowiązki obywatela, bliźniego i stanu [...] umiał dziwnie połączyć' (could the responsibilities of a citizen, neighbour and his class [...] exquisitely combine), while Salezy 'w obronie twojej wolności poległ' (fell, defending your freedom), at Szczekociny. ${ }^{78}$

What was the political and social culture of the nobility like? What were its ideals? It was certainly not egalitarian. Social inequality was obvious in it and commonly accepted, but conditioned not merely by the antiquity of a family. Social advance should result from services to the community, the king and the homeland. Responsibility and service were not a defunct idea; a nobleman had to serve at every stage of social hierarchy - and it should be a service not only to the elite, but also to those of a lower position. An epitaph was an exemplification of these principles: on the walls of a church examples of appropriate, commendable, and worth of being propagated behaviour were commemorated, linked closely to the dramatic history of the Commonwealth. They exhorted people to civic service during peacetime transformations, to bravery and dedication during a war, and to acquiring knowledge in times of intellectual revival. The relativism of current needs was not a reason to reject old models: they remained in memory to revive in due time. Today, when speaking of the patriotic education, we should remember - as our ancestors did - Seneca's words: 'Longum iter per praecepta, breve et efficax per exempla'.

\section{Translated by Kamil O. Kuraszkiewicz}

First published as: 'Kultura polityczna i społeczna szlachty sandomierskiej w świetle inskrypcji nagrobnych', Odrodzenie i Reformacja w Polsce, 50, 2006, pp. 75-87.

$761 / 1$, pp. $110,112,117$, cf. $1 / 5$, p. $90,1757$.

$77 \quad 1 / 5$, p. $90,1762$.

$781 / 2$, pp. 162, 163. 